\title{
Genetic Variability Studies in Gossypium barbadense L. Genotypes for Seed Cotton Yield and its Yield Components
}

\author{
N. Premalatha ${ }^{1 *}$, L. Mahalingam ${ }^{1}$, M. Kumar ${ }^{2}$ and S. Rajeswari ${ }^{1}$ \\ ${ }^{1}$ Department of Cotton, Centre for Plant Breeding and Genetics, Tamil Nadu Agricultural \\ University, Coimbatore - 641 003, India \\ ${ }^{2}$ Technical and Personal officer to the Vice-Chancellor, TNAU, Coimbatore, India \\ *Corresponding author
}

\section{A B S T R A C T}

\section{Keywords}

Cotton, Gossypium barbadense L., per se performance, genetic variability, heritability and genetic advance

\section{Article Info}

\section{Accepted:}

10 May 2020

Available Online:

10 June 2020
A total of one hundred and sixty germplasm accessions of Gossypium barbadense were evaluated for sixteen traits to assess their per se performance, variability, heritability, genetic advance, correlation and path analysis. The analysis of variance had shown significant differences between the genotypes for all the traits indicating the presence of sufficient variability in the experimental material. Based on the per se performance and range in G. barbadense, the accessions viz., Giza 45, CCB-1, 26/5W, CBS 202, EC111248, 32/2R, SIA-9 and K 2308 exhibited desirable values for the characters viz., single plant yield, boll weight, seed index, Upper half mean length, fibre strength, micronaire value, uniformity ratio and elongation percentage. PCV was higher than the GCV for all the studied characters. This denotes that all the traits under the investigation were influenced by the environmental effects. High heritability along with high genetic advance was observed in traits like plant height, number of bolls per plant, seed index, lint index, boll weight, micronaire and single plant yield per plant. These characters need to be given more importance during selection as these traits were governed by additive genes and hence selection of genotypes based on these characters would be effective. Correlation studies revealed that single plant yield had highly positive significant association with number of sympodia per plant, number of bolls per plant and boll weight. Hence selection based on these characters will help in improving the seed cotton yield.

\section{Introduction}

Cotton is one of the most important fibre and cash crop of India and plays a dominant role in the industrial and agricultural economy of the country. It provides the basic raw material to cotton textile industry. Cotton crop not only provides fibre for the textile industry, but also plays a role in the feed and oil industries with its seed, rich in oil and protein. Germplasm is the one which contains higher amount of genetic variability so it is composed of lines which have diversity in genes and alleles conferring different ranges of yield and fibre quality traits. The value of germplasm can be known only when it is properly characterized.

The successful breeding program and effective management of plant genetic resources depends on the ability to distinguish genotypes and to identify distant elite lines from germplasm resources (Owen et al., 2005). 
Genetic variability is the most important attribute which decides the success of a breeding programme. Though the trait is highly variable, it will be useful only if it passes on to the next generations with certain amount of heritability. For a character having high heritability only, a simple selection process will be effective. The knowledge of heritability and genetic advance helps us to assess the relative degree of a character transmitting to its progenies. An insight into the magnitude of variability present in a crop species is of utmost importance as it provides the basis for effective selection. The phenotype of a character is the resultant of interaction between the genotype and environment. Partitioning of observed variability into heritable and non- heritable components is essential to get a true indication of the genetic variation of the trait. Heritability measures the relative amounts of the heritable portion of variability while the genetic advance (GA) helps to measure the amount of progress that could be expected with selection in a character. The information on variability and heritability of characters is essential for identifying characters amenable to genetic improvement through selection. High heritability coupled with high genetic advance indicates additive gene effect (Johnson et al., 1955) and improvement could be made for that character by simple selection based on phenotypic performance. Low genetic advance irrespective of high or low heritability leads to non-additive gene action (Panse, 1957) and improvement of that trait by simple selection may not be rewarding (Verma et al., 1987). Hence, a study was conducted to realize the genetic advancement, variability and genetic variation among different accessions of upland cotton for yield, yield related traits and fibre quality traits. Therefore, for successful crop improvement, it is necessary to have a thorough knowledge on the variability present in the breeding material used for the study. In the present study, 160 cotton germplasm lines showed difference in all the characters. Heritability, genetic advance, genotypic, phenotypic and environment variance and response to selection were also calculated.

\section{Materials and Methods}

The field experiment was conducted with the 160 Gossypium barbadense germplasm accessions during kharif 2018-19 at Department of Cotton, Centre for Plant Breeding and Genetics, Tamil Nadu Agricultural University, Coimbatore in a Randomized block design with two replications. Each genotype was sown in one row of $6 \mathrm{~m}$ length with spacing of $90 \mathrm{~cm} \mathrm{x} 45$ $\mathrm{cm}$. Recommended package of practices and plant protection measures were adapted to raise a good crop. Observations on days to first flowering, days to $50 \%$ flowering, plant height, number of monopodia, number of sympodia, boll weight, number of bolls, seed index, lint index, ginning outturn, seed cotton yield per plant, were recorded on five randomly selected plants .Fibre quality characters viz., fibre length(mm), fibre strength (g/tex), micronaire value $(\mu /$ inch $)$, elongation percentage and uniformity ratio were analyzed under high volume instrument (HVI) at Department of Cotton, CPBG, TNAU, Coimbatore.

\section{Results and Discussion}

In this study, the $160 \quad G$. barbadense accessions were taken and a total of fifteen characters viz., days to first flowering, days to fifty per cent flowering, plant height $(\mathrm{cm})$, number of monopodia per plant, number of sympodia per plant, number of bolls per plant, boll weight $(\mathrm{g})$, single plant yield $(\mathrm{g})$, lint index, seed index, ginning outturn (\%), UHML (mm), fibre strength (g/tex), micronaire value $(\mu \mathrm{g} / \mathrm{inch})$ and elongation percentage were observed. The first and foremost criterion for selection is the mean 
performance. Among the study materials, the accessions which are identified as potential donors for the improvement of different characters are depicted in Table 1. Based on per se performance, the accessions Giza 45 and CBS 202 were identified as potential donors which recorded maximum values and also showed significantly higher values than the mean, for the traits, number of sympodia per plant, number of bolls per plant, ginning outturn and single plant yield per plant. These accessions may be exploited for further improvement of the above traits by breeding programme. Regarding the identification of donor for specific trait, the highest performer of that particular trait can be considered. These genotypes will serve as the source for selection of parent for improving a particular trait. The identified accessions can be utilized in breeding programme for the improvement of Egyptian cotton varieties and as donors for $\mathrm{h} \mathrm{x}$ b hybrids in overall ELS cotton improvement in India.

The analysis of variance for the sixteen characters under study is presented in Table 1 for the $160 \mathrm{G}$. barbadense accessions. The variations were significant among the genotypes for all the characters indicating the presence of significant genetic variability in the genotypes studied. The estimates of individual genotypes along with character wise mean, range, phenotypic coefficient of variation (PCV), genotypic coefficient of variation (GCV), heritability $\left(h^{2}(b)\right)$ and genetic advance as per cent of mean (GAM) were calculated and are presented in Table 2.

The variation in number of days to $50 \%$ flowering ranged from $59(26 / 5 \mathrm{~W})$ to 82 (EC 97638) days with grand mean of 69.4 days. The estimates of PCV (7.79) and GCV (7.06) were low, which indicates that this trait is less influenced by the environment. The results are in accordance with the results of Reddy et al., (2008). High heritability (82.1) coupled with low genetic advance as per cent of mean 13.17 was observed for days to $50 \%$ flowering, may be due to less variation and less number of genes governing this trait. So selection of this trait needs high intensity. This result fall in line with Dhivya et al., ( 2014). Plant height varied from $73.40 \mathrm{~cm}$ (Menoubi) to $166.7 \mathrm{~cm}$ (DB-5) with grand mean of $108.33 \mathrm{~cm}$. The estimates of PCV (16.81) and GCV (15.52) were moderate. This result fall in line with Vinodhana et al., (2013), Vineela (2013) and Ranganatha et al., (2015). High heritability (85.3) coupled with high genetic advance as per cent of mean (29.52) was observed for plant height indicating the role of additive gene action in the inheritance of this trait. These findings are in agreement with the result Vinodhana et al., (2013) and Chaudhari et al., (2017).

The number of monopodia per plant ranged from 0.0 to 1.5 with grand mean of 0.73 . The estimates of PCV (85.85) and GCV (22.33) were high. Similar findings were reported by Vijayalaxmi (2007). Moderate heritability coupled with high genetic advance as per cent of mean was observed for this trait. Similar findings were reported by Vijayalaxmi (2007). The number of sympodia per plant ranged from 7 (Menoubi) to 17 (Giza 45 and EC $136452 / \mathrm{B})$ with grand mean of 12.49 . The estimates of PCV (16.22) and GCV (11.87) were moderate and moderate heritability (53.6) coupled with moderate genetic advance as per cent of mean (17.9) was recorded for number of sympodia per plant. Similar findings were reported by Sakthi et al., (2007) Neelinaa and Reddy (2008) and Patel et al., (2013).

The number of bolls per plant ranged from 6 (Pima S4) to 25 (Giza 45) with grand mean of 15.38. The estimates of PCV (21.98) and GCV (20.96) were high and smilar findings were reported by Vinodhana et al., (2013) and Shakeel et al., (2015). 
High heritability (90.9) coupled with high genetic advance as per cent of mean (41.17) was recorded for number of bolls per plant. High heritability accompanied with high genetic advance indicates that most likely the heritability is due to additive gene effects and selection will be effective. These findings are in agreement with the result Dhivya et al., (2014) and Khan et al., (2015).

The boll weight per boll of a plant ranged from 2.4 (EC $9261 \mathrm{~B}) \mathrm{g}$ to $4.4 \mathrm{~g} \quad$ (CCB-1) with grand mean of 3.63. The estimates of PCV (12.44) and GCV (10.77) were moderate indicating the need for rigourous selection for the improvement of this trait. High heritability (74.8) coupled with moderate genetic advance as per cent of mean (19.16) was recorded for this trait. These results fall in line Ahsan et al., (2015a) and Farooq et al., (2017). For this trait simple selection process can be sufficient.

Seed index was in the range of $6.1 \mathrm{~g}$ (SIV $135-8)$ to $11.6 \mathrm{~g}(26 / 5 \mathrm{~W})$ with grand mean of $8.96 \mathrm{~g}$. The estimates of PCV (13.66) and GCV (12.98) were moderate and this is in accordance with Dhivya et al., (2014). High heritability (90.1) and high genetic advance as per cent of mean (25.38) were observed for this trait. Similar results were recorded by Dhivya et al., (2014) and Narendra (2015). The range observed for the lint index was from $2.8 \mathrm{~g}$ (EC 97625) to $6.40 \mathrm{~g}$ (CBS 202) with grand mean of $4.54 \mathrm{~g}$. The estimates of PCV (17.33) and GCV (16.36) were moderate and these findings are in accordance with the results of Dhivya et al., (2014) and Reddy et al., (2015). High heritability (89.1) coupled with high genetic advance as per cent of mean (31.81) was observed for lint index. Similar results was observed by Ahsan et al., (2015 a and 2015 b) and Rajamani et al., (2015). The range among the genotypes for ginning outturn was $27.6 \%$ (32/2R) to $38.5 \%$ ( Giza 45 ) with grand mean of $33.4 \%$. It showed low
PCV (8.69) and low GCV (6.26) and the difference between the estimates were also low indicating that this trait is less influenced by the environment. Similar results were reported by Reddy et al., (2015). Moderate heritability (51.9) coupled with low genetic advance as per cent of mean (9.3) was recorded. These results are in line with Khan et al., (2015).

The single plant yield ranged from $21.0 \mathrm{~g}$ (Monspi serrate) to $103.0 \mathrm{~g}$ (Giza 45) with grand mean of $59.16 \mathrm{~g}$. The estimates of PCV (24.07) and GCV (22.16) were high. This was in line with the findings of Dhivya et al., (2014) and Reddy et al., (2015). High heritability (84.8) coupled with high genetic advance as per cent of mean (42.03) was observed for seed cotton yield per plant, indicating the operation of additive genes in the inheritance of seed cotton yield and directional selection for this trait in genetically diverse material could be effective for desired genetic improvement. This finding is in conformity with the results obtained by Dhivya et al., (2014), Khan et al., (2015) and Narendra (2015).

The upper half mean length ranged from 29.5 $\mathrm{mm}$ (TCB 372) to $38.3 \mathrm{~mm}$ (EC 111248) with grand mean of $33.01 \mathrm{~mm}$. The estimates of PCV (6.06) and GCV (4.68) were low. There is a close correspondence between PCV and GCV estimates indicating less environmental influence over the expression of this character. These results are in accordance with Dhivya et al., (2014) and Reddy et al., (2015). High heritability (59.8) coupled with low genetic advance as per cent of mean (7.46) was observed for this trait. Rajanna (2010) observed similar results for this trait. The range for fibre strength was from $24.8 \mathrm{~g} / \mathrm{tex}$ (Nevis) to $36.1 \mathrm{~g} /$ tex $(32 / 2 \mathrm{R})$ with grand mean of $29.16 \mathrm{~g} /$ tex. The estimates of PCV (9.10) and GCV (4.01) were low with very close correspondence. 
Table.1 Mean and range of performance for different characters among the accessions of $G$. barbadense

\begin{tabular}{|l|c|c|c|}
\hline \multirow{2}{*}{ Characters } & \multicolumn{3}{|c|}{ Germplasm accessions } \\
\hline Days to flowering & Mean & Maximum value & Minimum value \\
\hline Days to 50\% flowering & 53 & 75 & $\mathbf{6 3 . 4 6}$ \\
\hline Plant height (cm) & 59 & 82 & $\mathbf{6 9 . 4 0}$ \\
\hline Number of monopodia & 73.4 & 166.7 & $\mathbf{1 0 8 . 3 3}$ \\
\hline Number of sympodia & 1.0 & 1.5 & $\mathbf{1 2 . 4 9}$ \\
\hline Number of bolls & 7.0 & 17.0 & $\mathbf{1 5 . 3 8}$ \\
\hline Boll weight $(\mathbf{g})$ & 6.0 & 25.0 & $\mathbf{3 . 6 3}$ \\
\hline Lint index & 2.4 & 4.4 & $\mathbf{4 . 5 4}$ \\
\hline Seed index & 2.8 & 6.4 & $\mathbf{8 . 9 6}$ \\
\hline Ginning outturn $(\boldsymbol{\%})$ & 6.1 & 11.6 & $\mathbf{3 3 . 4 0}$ \\
\hline Seed cotton yield (g) & 27.6 & 38.5 & $\mathbf{5 9 . 1 6}$ \\
\hline Upper Half Mean Length $(\mathbf{m m})$ & 21.0 & 103.0 & $\mathbf{3 3 . 0 1}$ \\
\hline Fibre strength $(\mathbf{g} /$ tex) & 29.5 & 38.3 & $\mathbf{2 9 . 1 6}$ \\
\hline Micronaire value $(\boldsymbol{\mu g} /$ inch) & 24.8 & 36.1 & $\mathbf{3 . 1 1}$ \\
\hline Uniformity ratio $(\%)$ & 2.10 & 3.90 & $\mathbf{8 3 . 4 9}$ \\
\hline Elongation percent & 69.8 & 88.8 & $\mathbf{6 . 0 1}$ \\
\hline
\end{tabular}

Table.2 Potential donors for yield related traits and fibre quality traits

\begin{tabular}{|c|c|}
\hline Characters & Potential accessions \\
\hline Days to $50 \%$ flowering & EC 9261 (B), 26/5W, 3530, TCB 472/4, 85/2, 6002-1, Sudan G-5-S, SB 1085-6, N 28 \\
\hline Plant height $(\mathrm{cm})$ & $\begin{array}{l}\text { DB- 5, Giza, EC 136452/B, CBS 202, SIV 135-8, EC 111265, CBS 148, Sudan G-45, Giza 7(A), EC 97638, } \\
\text { EC 97632/4, EC 97635, 3415 A, EC 9257, EC 97620, Giza 1467, EC } 97628\end{array}$ \\
\hline $\begin{array}{l}\text { Number of sympodia } \\
\text { per plant }\end{array}$ & $\begin{array}{l}\text { EC 136452/B, Giza 45, EC 136450, EC 9257, EC 97620, EC 111254, EC 131979, Giza 7(A), RHCB 01, } \\
\text { RAB } 107\end{array}$ \\
\hline Number of bolls per plant & $\begin{array}{l}\text { Giza 45, Barbados, CBS 202, EC 126597, EC 136452/B, EC 9257, Giza 7(A), SB 1085-6, CCB-1, } \\
\text { CBS 201, EC 131979, Suvin, GSB 39, RAB } 107\end{array}$ \\
\hline Boll weight $(\mathrm{g})$ & $\begin{array}{l}\text { CCB-1, 32/2R, BCS 59-19, SIA-4, SIA-5, CBS 201, EC 9256, EC 97628, 6002-1, CCB-3, EC } 97640 \\
\text { 32/1W, 5391-T, CCB-2, EC 9255, EC 97634, EC 101783, EC 111248, 22/2R, 5904-U , BCS 9-45 }\end{array}$ \\
\hline Lint index & $\begin{array}{l}\text { CBS 202, EC 136452/B, EC 97620, RHCB 01, EC 136451, 17/3A, EC 97632, Sudan G-45, TCB 404, } \\
\text { 26/5W } \\
\text { ERB 4492, 32/1W, TCB 355, SB 1085-6, Suvin, 7822-5 }\end{array}$ \\
\hline Seed index & $\begin{array}{l}\text { 26/5W, EC 136452/B, CCB-3, EC 136451, Egyptian, 32/1W, Giza 1467, IBSI, RHCB 01, ERB 4492, CBS } \\
\text { 202, } \\
\text { IBSI 53, TCB 404, EC 9260, G-122-A-45, EC 101785, EC 97624, EC 97639, TCB 377, 32/2R, Seaberry } \\
\text { 528, 17/3A, SIA-5, 13-2 }\end{array}$ \\
\hline Ginning outturn $(\%)$ & Giza 45, 19/2, EB(A), SIV RB ,N 28, Suvin, BCS 9-45, SBS (YF), Sudan G-45, 13-2, RHCB 01 \\
\hline Single plant yield $(\mathrm{g})$ & $\begin{array}{l}\text { Giza 45, Barbados, CBS 201, CBS 202, } \\
\text { EC 126597, EC 131979, EC 9260, EC 97628, BCS 9-45, EC 136452/B, CCB-1 }\end{array}$ \\
\hline UHML(mm) & $\begin{array}{l}\text { EC 111248, 85/2, EC 97634, CCB-1, 3530, CCB-3, 83/1W, EC 9260, SIA-9, TNB -1, EC 97635, SIV 135- } \\
6,5904-U, 82 / 2 R \text {, TCB 371, EC } 97631,5391-\mathrm{T}, 32 / 1 \mathrm{~W}, 22 / 2 \mathrm{R}\end{array}$ \\
\hline Fibre strength $(\mathrm{g} / \mathrm{tex})$ & $\begin{array}{l}32 / 2 \mathrm{R}, 22 / 2 \mathrm{R}, 83 / 1 \mathrm{~W}, 3530 \mathrm{U}, 16 / 2 \mathrm{~W}, 6002, \mathrm{CCB}-4 \\
76 / 3, \mathrm{TCB} 472 / 4, \mathrm{CCB}-1\end{array}$ \\
\hline Micronaire value ( $\mu \mathrm{g} / \mathrm{inch})$ & $\begin{array}{l}\text { SIA -9, 17/3B, Bar x Xu, EC 97627, G-122-A-45, Nevis, TCB 209, EC 97618, EC 111248, PSH, N 28, } \\
\text { Pima SI, SBS 49, Sudan G-55, } 3415 \text { A }\end{array}$ \\
\hline Elongation percentage & K 3530, St. Kitts, Suvin, TCB 209 \\
\hline
\end{tabular}


Table.3 Analysis of variance for the various characters between the germplasm accessions of Gossypium barbadense

\begin{tabular}{|l|c|c|c|}
\hline \multirow{2}{*}{ Characters } & \multicolumn{3}{|c|}{ Mean Sum of squares } \\
\hline Days to flowering & Replication & Treatment & Error \\
\hline Days to 50\% flowering & 10.15 & $51.78^{*}$ & 4.67 \\
\hline Plant height (cm) & 13.61 & $52.71^{*}$ & $\mathbf{5 . 1 7}$ \\
\hline Number of monopodia & 39.9 & $610.14^{*}$ & $\mathbf{4 8 . 5 6}$ \\
\hline Number of sympodia & 0.028 & 0.371 & $\mathbf{0 . 4 2 4}$ \\
\hline Number of bolls & $22.58^{*}$ & $5.99^{*}$ & $\mathbf{1 . 8 1}$ \\
\hline Boll weight (g) & $145.80^{*}$ & $21.54^{*}$ & $\mathbf{1 . 0 3}$ \\
\hline Lint index & $7.14^{*}$ & $0.351^{*}$ & $\mathbf{0 . 0 5}$ \\
\hline Seed index & $0.59^{*}$ & $1.16^{*}$ & $\mathbf{0 . 0 7}$ \\
\hline Ginning outturn (\%) & $1.54^{*}$ & $2.83^{*}$ & $\mathbf{0 . 1 5}$ \\
\hline Seed cotton yield (g) & 6.7 & $12.77^{*}$ & $\mathbf{4 . 0 4}$ \\
\hline Upper Half Mean Length $(\mathbf{m m})$ & $6750.05^{*}$ & $374.39^{*}$ & $\mathbf{3 0 . 8 6}$ \\
\hline Bundle strength $(\mathbf{g} /$ tex) & $20.8^{*}$ & $6.37^{*}$ & $\mathbf{1 . 6}$ \\
\hline Micronaire value $(\boldsymbol{\mu g} /$ inch) & $24.81^{*}$ & $8.4^{*}$ & $\mathbf{5 . 6 7}$ \\
\hline Uniformity ratio & $0.95^{*}$ & $0.42^{*}$ & $\mathbf{0 . 0 3}$ \\
\hline Elongation percent & 3.98 & 5.43 & $\mathbf{4 . 9}$ \\
\hline
\end{tabular}

*significant (5\% level), **significant (1\% level)

Similar results for this trait was reported by Vinodhana et al., (2013) and Reddy et al., (2015). Low heritability (19.43) coupled with low genetic advance as per cent of mean (3.64) was recorded for this trait, indicating the operation of both additive and nonadditive genes. Similar results were reported by Srinivasulu et al., (2009).

The range for the micronaire value varied from $2.1 \mu \mathrm{g} /$ inch (SIA -9) to $3.9 \mu \mathrm{g} / \mathrm{inch}$ (Suvin) with grand mean of $3.11 \mu \mathrm{g} / \mathrm{inch}$. The estimates of PCV (15.38) and GCV (14.25) were moderate. These findings are in agreement with the results of Reddy et al., (2015). High heritability (85.8) coupled with high genetic advance as per cent of mean (27.19) was observed for this trait, indicating the role of additive gene action in the inheritance of this trait and simple selection will be highly rewarding for improving micronaire value. These results are in agreement with the findings of Narendra (2015). The range was 69.8 (BCS 59-19) to 88.8 (EC 9255) with grand mean of 83.49 for uniformity ratio. The estimates of PCV (2.73) and GCV (0.58) were low. Similar results were recorded by Usharani et al., (2014) and Reddy et al., (2015). High heritability (64.5) coupled with low genetic advance as per cent of mean (0.25) was observed for uniformity ratio. Similar results were recorded by Srinivasulu et al., (2009).

The range of variation observed was 5.6\% (ERB 4530) to $6.6 \%$ (K 2308) with grand mean of $6.01 \%$ for elongation percentage. The estimates of PCV (3.65) and GCV (1.96) were low indicating the lower contribution of this trait towards the total variability. Similar results were recorded by Usharani et al., (2014) and Reddy et al., (2015). 
Table.4 Variability, heritability and genetic advance as percent mean

\begin{tabular}{|c|c|c|c|c|c|c|c|c|c|}
\hline Characters & $\mathbf{V P}$ & VE & VG & Mean & PCV & GCV & Heritability & GA & GAM \\
\hline Days to flowering & 28.22 & 4.67 & 23.56 & 63.46 & 8.41 & 7.68 & 0.84 & 9.13 & 14.46 \\
\hline Days to $50 \%$ flowering & 28.99 & 5.18 & 23.81 & 69.4 & 7.79 & 7.06 & 0.82 & 9.11 & 13.17 \\
\hline Plant height (cm) & 329.35 & 48.56 & 280.8 & 108.33 & 16.81 & 15.52 & 0.85 & 31.87 & 29.52 \\
\hline Number of monopodia & 0.4 & 0.42 & -.0 .027 & 0.73 & 85.45 & 22.33 & -0.07 & -0.09 & -11.96 \\
\hline Number of sympodia & 3.9 & 1.81 & 2.09 & 12.49 & 16.22 & 11.87 & 0.54 & 2.18 & 17.9 \\
\hline Number of bolls & 11.29 & 1.03 & 10.26 & 15.38 & 21.98 & 20.96 & 0.91 & 6.29 & 41.16 \\
\hline Boll weight (g) & 0.20 & 0.05 & 0.15 & 3.63 & 12.44 & 10.76 & 0.75 & 0.69 & 19.16 \\
\hline Lint index & 0.61 & 0.07 & 0.55 & 4.54 & 17.33 & 16.36 & 0.90 & 1.43 & 31.81 \\
\hline Seed index & 1.49 & 0.15 & 1.35 & 8.96 & 13.68 & 12.99 & 0.90 & 2.27 & 25.38 \\
\hline Ginning outturn (\%) & 8.41 & 4.04 & 4.37 & 33.4 & 8.69 & 6.26 & 0.52 & 3.10 & 9.29 \\
\hline Seed cotton yield (g) & 202.63 & 30.86 & 171.77 & 59.16 & 24.07 & 22.16 & 0.85 & 24.86 & 42.03 \\
\hline Upper Half Mean Length (mm) & 3.99 & 1.6 & 2.38 & 33.01 & 6.06 & 4.68 & 0.6 & 2.46 & 7.46 \\
\hline Bundle strength (g/tex) & 7.03 & 5.67 & 1.37 & 29.16 & 9.10 & 4.01 & 0.19 & $1 ` .06$ & 3.64 \\
\hline Micronaire value ( $\mu \mathrm{g} / \mathrm{inch})$ & 0.22 & 0.03 & 0.19 & 3.11 & 15.38 & 14.25 & 0.86 & 0.83 & 27.19 \\
\hline Uniformity ratio (\%) & 5.19 & 4.96 & 0.23 & 83.49 & 2.73 & 0.58 & 0.65 & 0.21 & 0.25 \\
\hline Elongation percent & 0.4 & 0.03 & 0.01 & 6.01 & 3.65 & 1.96 & 0.29 & 0.13 & 2.74 \\
\hline
\end{tabular}




\section{Int.J.Curr.Microbiol.App.Sci (2020) 9(6): 01-12}

Table.5 Genotypic correlation coefficients for morphological traits associated with single plant yield

\begin{tabular}{|c|c|c|c|c|c|c|c|c|c|c|c|c|c|c|}
\hline Traits & DFF & D5F & PH & NSP & NBP & BW & LI & SI & GOT & UHML & FS & Mic & EP & SPY \\
\hline DFF & 1.000 & $1.003^{* * *}$ & 0.026 & 0.084 & 0.104 & -0.064 & -0.017 & 0.061 & 0.046 & -0.020 & $-0.210^{*}$ & 0.037 & -0.128 & 0.103 \\
\hline D5F & & 1.000 & 0.053 & 0.097 & 0.119 & -0.044 & -0.029 & 0.052 & 0.040 & -0.016 & $-0.227^{*}$ & 0.036 & -0.185 & 0.156 \\
\hline PH & & & 1.000 & $0.473^{* *}$ & $0.238^{*}$ & -0.073 & $0.199 *$ & 0.019 & 0.113 & -0.071 & $-0.242 *$ & 0.067 & 0.099 & $0.262 * *$ \\
\hline NSP & & & & 1.000 & $0.692 * *$ & -0.085 & 0.167 & -0.089 & 0.178 & 0.051 & $-0.394 * *$ & 0.005 & -0.172 & $0.719 * *$ \\
\hline NBP & & & & & 1.000 & -0.048 & 0.147 & 0.027 & 0.169 & 0.089 & 0.096 & 0.072 & 0.084 & $0.895^{* *}$ \\
\hline BW & & & & & & 1.000 & -0.024 & 0.084 & $-0.230 *$ & $0.333^{* *}$ & $0.273^{* *}$ & 0.127 & -0.024 & $0.383 * *$ \\
\hline LI & & & & & & & 1.000 & $0.623^{* *}$ & $0.598 * *$ & -0.017 & 0.049 & 0.145 & 0.191 & 0.096 \\
\hline SI & & & & & & & & 1.000 & $-0.258^{* *}$ & 0.161 & $0.310^{* *}$ & 0.122 & 0.118 & 0.006 \\
\hline GOT & & & & & & & & & 1.000 & $-0.290^{* *}$ & $-0.430 * *$ & 0.062 & 0.135 & 0.064 \\
\hline UHML & & & & & & & & & & 1.000 & $0.790 * *$ & 0.063 & $0.380^{* *}$ & 0.147 \\
\hline FS & & & & & & & & & & & 1.000 & $\begin{array}{c}- \\
0.121\end{array}$ & $0.591 * *$ & 0.069 \\
\hline Mic & & & & & & & & & & & & 1.000 & $0.196^{*}$ & 0.096 \\
\hline EP & & & & & & & & & & & & & 1.000 & -0.029 \\
\hline SPY & & & & & & & & & & & & & & 1.000 \\
\hline
\end{tabular}

*significant $(5 \%$ level), **significant (1\% level) 
Int.J.Curr.Microbiol.App.Sci (2020) 9(6): 01-12

Table.6 Phenotypic correlation coefficients for morphological traits associated with single plant yield

\begin{tabular}{|c|c|c|c|c|c|c|c|c|c|c|c|c|c|c|}
\hline Traits & DFF & D5F & PH & NSP & NBP & BW & LI & SI & GOT & UHML & FS & Mic & EP & SPY \\
\hline DFF & 1.000 & $0.976 * *$ & -0.006 & 0.059 & 0.081 & -0.048 & -0.008 & 0.052 & -0.003 & -0.017 & -0.105 & 0.001 & -0.084 & 0.077 \\
\hline D5F & & 1.000 & 0.012 & 0.087 & 0.107 & -0.031 & -0.023 & 0.024 & -0.028 & -0.015 & -0.130 & 0.003 & -0.102 & 0.108 \\
\hline PH & & & 1.000 & $0.401^{* *}$ & $0.224^{*}$ & -0.050 & 0.146 & 0.010 & 0.109 & -0.062 & -0.126 & 0.045 & 0.037 & $0.214 *$ \\
\hline NSP & & & & 1.000 & 0.553 & -0.002 & 0.030 & -0.063 & 0.070 & 0.000 & -0.110 & 0.005 & -0.020 & 0.469 ** \\
\hline NBP & & & & & 1.000 & -0.030 & 0.116 & 0.011 & 0.119 & 0.042 & 0.041 & 0.069 & 0.061 & 0.804 ** \\
\hline BW & & & & & & 1.000 & -0.028 & 0.075 & -0.172 & 0.166 & 0.115 & 0.114 & 0.015 & $0.302 * *$ \\
\hline LI & & & & & & & 1.000 & $0.581^{* *}$ & $0.448^{* *}$ & -0.005 & 0.023 & 0.134 & 0.113 & 0.092 \\
\hline SI & & & & & & & & 1.000 & -0.160 & 0.147 & 0.176 & 0.111 & 0.079 & 0.005 \\
\hline GOT & & & & & & & & & 1.000 & -0.161 & -0.075 & 0.049 & 0.012 & 0.086 \\
\hline UHML & & & & & & & & & & 1.000 & $0.352 * *$ & 0.008 & 0.126 & 0.099 \\
\hline FS & & & & & & & & & & & 1.000 & -0.010 & $0.287^{* *}$ & 0.062 \\
\hline Mic & & & & & & & & & & & & 1.000 & $0.132 *$ & 0.083 \\
\hline EP & & & & & & & & & & & & & 1.000 & -0.066 \\
\hline SPY & & & & & & & & & & & & & & 1.000 \\
\hline
\end{tabular}

*significant (5\% level), **significant (1\% level) 
Low heritability (28.8) coupled with low genetic advance as per cent of mean (2.17) was observed for elongation percentage. This indicates that the characters are highly influenced by environmental effects and selection would be ineffective in such cases. These results fall in line with Eswararo (2008).

Variability studies revealed that phenotypic and genotypic coefficient of variation exhibited wide range for all sixteen characters. High PCV and GCV were observed for number of monopodia per plant, number of bolls per plant and single plant yield per plant. Characters like plant height, number of sympodia per plant, boll weight, seed index and lint index shown moderate PCV and moderate GCV. Low PCV and low GCV observed for days to $50 \%$ flowering, ginning outturn, upper half mean length, fibre strength, uniformity ration and elongation percentage. High heritability along with high or moderate genetic advance as percent mean were showed by characters plant height, number of bolls per plant, seed index, lint index, boll weight, micronaire and single plant yield per plant are under the control of additive gene action and directional selection for these traits in the genetically diverse material could be effective for desired genetic improvement. Hence, it may be concluded these characters are considered as suitable for effective selection in breeding programme.

Among the 16 characters studied, the correlation studies indicated that the number of bolls per plant, number of sympodia per plant and boll weight showed positive and significant correlation with single plant yield, which is in confirmation with the results of Shazia Salahuddin et al., (2010) where the number of bolls per plant showed positive and significant correlation with the single plant yield per plant in upland cotton. Apart from that, the characters such as number of sympodia per plant and boll weight, showed positive and significant correlation with the single plant yield as reported by Srinivasulu et al., (2009) in Egyptian cotton. Inter correlation among the traits also play a vital role in selection.

The inter correlation between the quantitative yield contributing traits viz., number of sympodia per plant, number of bolls per plant, lint index, see d index, ginning outturn, upper half mean length, fibre strength and elongation percentage were positive and significant. Plant height showed positive and highly significant genotypic correlation with number of sympodia per plant, number of bolls per plant and lint index. Number of sympodia per plant showed positive and highly significant genotypic correlation with number of bolls per plant. Boll weight showed highly significant positive genotypic correlation with upper half mean length and fibre strength. Lint index showed positive and highly significant genotypic correlation with seed index and ginning outturn. Seed index showed positive and highly significant genotypic correlation with fibre strength. Upper half mean length showed positive and highly significant genotypic correlation with fibre strength and elongation percentage. Fibre strength showed positive and highly significant genotypic correlation with elongation percentage.

\section{References}

Ahsan, M.Z., M.A. Laghari, H. Bhutto, A.W. Soomro, M.S. Majidano, and T.H. Malik. 2015a. Genetic variability in different biometric traits of upland cotton genotypes. Int. J. Biol. Biotech., 12(4): 607-612.

Ahsan, M.Z., M.S. Majidano, H. Bhutto, A.W. Soomro, F.H. Panhwar, A.R. Channa and K.B. Sial. 2015b. Genetic variability, coefficient of variance, 
heritability and genetic advance of some Gossypium hirsutum L. accessions. J. Agric. Sci., 7: 147-151.

Chaudhari, M., Faldu, G., and Ramani, H. (2017). Genetic variability, Correlation and Path coefficient analysis in cotton (Gossypium hirsutum L.). Advances in Bioresearch, 8(6).

Dhivya, R., P. Amalabalu, R. Pushpa and D. Kavithamani. 2014. Variability, heritability and genetic advance in upland cotton (Gossypium hirsutum L.). Afr. J. Plant Sci., 8(1): 1-5.

Eswararao, G., V. Chenga Reddy, M. Lal Ahamed, V. Srinivasa Rao, C. Panduranga Rao, and V. Bali Reddy. 2008. Correlation and path coefficient analysis in cotton (Gossypium hirsutum L.). The Andhra Agric. J., 56(2): 192-195.

Farooq, J., Rizwan, M., Sharif, I., Chohan, S. S. S., and Kainth, R. (2017). Genetic diversity studies in some advanced lines of Gossypium hirsutum L. for yield and quality related attributes using cluster and principle component analysis. Advances in Agriculture and Botanics, 9(3), 111-118.

Johnson, H. W., H.F. Robinson, and R.E. Comstock. 1955. Estimates of genetic and environmental variability in soybean. Agronomy J. 47: 314-318.

Khan, F.Z., S.U. Rehman, M.A. Abid, W. Malik, C.M. Hanif Bilal, G. Qanmber, A. Latif, J. Ashraf, and U. Farhan. 2015. Exploitation of Germplasm for Plant Yield Improvement in Cotton (Gossypium hirsutum L.). J. Green Physio., Genet. Genom., 1 (1): 1-10.

Narendra, A. 2015. Variability, heritability and hereditary propel in upland cotton (Gossypium hirsutum L.). Int. J. Plant Breed. Genet., 2(2): 73-76.

Neelima, S. and V.C. Reddy. 2008. Genetic parameters of yield and fibre quality traits in American cotton (Gossypium hirsutum L.). Indian J. Agric. Res.,
42(1): $67-70$.

Owen, C. A., Bita, E.-C., Banilas, G., Hajjar, S. E., Sellianakis, V., Aksoy, U., Metzidakis, I. (2005). AFLP reveals structural details of genetic diversity within cultivated olive germplasm from the Eastern Mediterranean. Theoretical and Applied Genetics, 110(7), 11691176.

Panse, V. G. 1957. Genetics of quantitative characters in relation to plant breeding. Indian J. Genet. Plant Breed., 17: 318328.

Patel, S.M., N.A. Patel, M.B. Parmar, M.P. Patel, and J.A. Patel. 2013. Studies on variability parameters, correlation and path coefficient analysis in $B t$ cotton hybrids $(\mathrm{H} \times \mathrm{H})$. Crop Res., 46(1, 2 \&3): 212-216.

Patel, S.M., N.A. Patel, M.B. Parmar, M.P. Patel, and J.A. Patel. 2013. Studies on variability parameters, correlation and path coefficient analysis in $B t$ cotton hybrids $(\mathrm{H} \times \mathrm{H})$. Crop Res., 46(1, 2 \&3): 212-216.

Rajamani, S., P. Sumalatha, and M. Gopinath. 2015. Studies on genetic parameters of seed cotton yield and fiber traits in upland cotton (Gossypium hirsutum L.). J. Cotton Res. Dev., 29(1): 36-38.

Ranganatha, H., S. Patil, S. Manjula and B. Patil. 2013. Studies on heterosis in cotton (Gossypium hirsutum L.) for seed cotton yield and its components. Asian J. Plant Sci., 8:82-85.

Reddy, Y.R. and C.V.C.M. Reddy. 2008. Association and path analysis in inter and intraspecific hybrids of cotton. Plant Archives, 8(1): 355-357.

Sakthi, A. R., M. Kumar and R. Ravikesavan. 2007. Variability and association analysis using morphological and quality traits in cotton (Gossypium hirsutum L.). J. Cotton Res. Dev., 21(2):148- 152.

Shakeel, A., I. Talib, M. Rashid, A. Saeed, K. 
Ziaf and M.F. Saleem. 2015. Genetic diversity among upland cotton genotypes for quality and yield related traits. Pak. J. Agric. Sci., 52:73-77.

Shazia Salahuddin, Saifullah Abro, M.M., Kandhro, L., Salahuddin and Laghari, S. 2010. Correlation and path coefficient analysis of yield components of upland cotton (Gossypium hirsutum L.). World Applied Sciences Journal. 8 (special issue of Biotechnology and Genetic Engineering): 71-75.

Srinivasulu, P., J.S.V. Samba Murthy, P.V. Rama Kumar, and V. Srinivasa Rao. 2009. Multivariate analysis of genetic diversity in upland cotton (Gossypium hirsutum L.). The Andhra Agric. J., 57(2): 148-155.

Usharani, K., P. Vindhiyavarman and P. Amala Balu. 2014. Combining ability analysis in intraspecific F1 diallel cross of upland cotton (Gossypium hirsutum
L.). Electronic J. Plant Breed., 5:467474.

Verma, S., S. Singh, A.S. Mehta, B.P.S. Lather and U. Verma. 1987 Studies of heritability and variability for yield and variability for yield and its components in desi cotton (Gossypium hirsutum L.). Cotton Dev., 17 (1-2): 39-42.

Vijayalaxmi, G., V.C. Reddy, C.P. Rao, J.S. Babu and R. Srinivasulu. 2008. Multivariate analysis of genetic diversity in upland cotton (Gossypium hirsutum L.). The Andhra Agric. J. 56(2): 8-15.

Vineela, N. 2013. Heterosis for morpho physiological studies in cotton. J. Natural Sci., 1:53-64.

Vinodhana, K., M. Gunasekaran and P. Vindhiyavarman. 2013. Genetic studies of variability, correlation and path coefficient analysis in cotton genotypes. Int. J. Pure App. Biosci., 1:6-10.

\section{How to cite this article:}

Premalatha. N., L. Mahalingam, M. Kumar and Rajeswari. S. 2020. Genetic Variability Studies in Gossypium barbadense L. Genotypes for Seed Cotton Yield and its Yield Components. Int.J.Curr.Microbiol.App.Sci. 9(06): 01-12. doi: https://doi.org/10.20546/ijcmas.2020.906.001 